\title{
ANNOUNCEMENTS
}

\section{A.A.A. FIFTIETH ANNIVERSARY FOUNDATION}

The foundation aims at promoting the study and practice of international law, within the framework of the A.A.A. activities. Its aim is realized by all lawful means, and in particular by awarding scholarships to persons participating in A.A.A. activities, by offering prizes for studies in the field of international law, etc. The Board of Trustees of the foundation is presided by Mr. Hellmut Gösser, Judge (retired) at Düsseldorf.

We cordially invite all those who sympathise with the A.A.A. and with the objectives of the foundation to grant donations or requests in favour of "A.A.A. Fiftieth Anniversary Fund" - Laan Copes van Cattenburch 98, The Hague (Bank account of the Foundation: Spaarrekening 43.02.59.549 Amrobank, The Hague).

As before the foundation has decided to organize a competition for the year $1978 / 1979$, the Rules of which appear below.

1. The year 1978/1979 the Association of Attenders and Alumni of the Hague Academy of International Law (A.A.A.) will organize a competition for studies dealing with the following subject: "LEGAL ASPECTS OF ARTIFICIAL ISLANDS".

2. Award of Dfl. 1.000,-- (1.000 Dutch florins) will be issued for the best study on the above subject.

3. Each entry for the prize should be of the highest academic standing; it should not have been published before and must represent an original contribution of the subject.

4. The entry shall be of the order of about 9.000 words and be written in English or French.

5. Candidates for the prize shall submit their studies in four typewritten copies.

6. The final date for submission of entries is June 15, 1979 .

7. Entries should be sent to the Secretary General of the A.A.A., Laan Copes van Cattenburch 98, The Hague (Netherlands).

8 . The prize shall be awarded by a Jury composed of three members. The decision of the Jury shall be final.

9. The award of the prize does not imply agreement of the A.A.A. with the opinions expressed by the prizewinner.

10. The A.A.A. reserves the right to publish the prizewinning studies in its Yearbook or other publications.

11. The prize will be presented to the prizewinner at a working session of the next Congress of international law of the A.A.A. 